Published by LPMP Imperium

Journal homepage: https:/ / ejournal.imperiuminstitute.org/ index.php/ BERDAYA

\title{
Pelatihan Pengelolaan Keuangan Rumah Tangga Bagi Ibu-Ibu Rumah Tangga D i Cengkareng Barat Wilayah Jakarta Barat
}

\author{
Swarmilah Hariani ${ }^{*}$, Yulia Yustikasari ${ }^{2}$, Taufik A kbar ${ }^{3}$ \\ A kuntansi, Fakultas Ekonomi dan Bisnis, Universitas Mercubuana \\ *Email: swarmilah@ mercubuana.ac.id
}

\section{ABSTRACT}

This activity aims to increase understanding and knowledge of housewives in calculating and recording the receipt and expenditure of household cash properly so that expenses do not occur greater than income. So that the family's financial condition is always sufficient and has savings/ investment for future needs so that welfare is realized for the family. The method used in this activity is in the form of training or short household financial management training using the financial management module. Participants are given training with activities using the classical method of giving material and followed by question and answer sessions and exercises/practices; the provision of working papers filled in accordance with the real conditions of the participant. Participants in the activity are housewives who do not work, housewives who work, and housewives who have their own business with an average educational background through high school, as well as the economic background of middle and lower families can attend training well and enthusiastically.

Keywords: Household financial management, family welfare

\section{BERDAYA}

\section{5}

\section{Article History}

Received 12Jun 2019

Revised 13A ugust 2019

Accepted 18August 2019

First Published: 31 August

2019

\section{Reviewing Editor}

Hendryadi, Sekolah Tinggi

Ilmu Ekonomi Indonesia

Jakarta

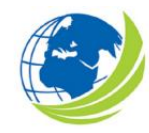

BERDAYA, Vol 1, No.1,

August 2019,

pp. 15-22

eISSN XXXX-XXXX

To cite this article:Hariani, S., Yustikasari, Y., \& Akbar, T. (2019). Pelatihan Pengelolaan Keuangan Rumah Tangga Bagi Ibu-l bu Rumah Tangga Di Cengkareng Barat Wilayah Jakarta Barat. BERD A Y A : Jurnal Pendidikan dan Pengabdian K epada M asyarakat,1(1), 15 - 22.

(c) $\bigodot_{\mathrm{BY}}$

(c) 2019 TheA uthor(s). This open access article is distributed under a Creative Commons Attribution (CC-BY) 4.0 license 


\title{
Pelatihan Pengelolaan Keuangan Rumah Tangga Bagi I bu-Ibu Rumah Tangga D i Cengkareng Barat Wilayah Jakarta Barat
}

\author{
Swarmilah Hariani ${ }^{1 *}$, Yulia Yustikasari², Taufik A kbar³ \\ Akuntansi, Fakultas Ekonomi dan Bisnis, Universitas Mercubuana \\ *Email: swarmilahharianiugm semacc@yahoo.com
}

\begin{abstract}
ABSTRAK
Kegiatan ini bertujuan untuk menambah pemahaman dan pengetahuan ibu rumah tangga dalam melakukan penghitungan dan pencatatan peneriman dan pengeluaran kas rumah tangga dengan baiksehingga tidak terjadi lebih besar pengeluaran daripada pendapatan. Sehingga kondisi keuangan keluarga selalu cukup dan mempunyai tabungan/ investasi untuk keperluan di masa depan, sehingga terwujud kesejahteraan bagi keluarga.Metode yang digunakan dalam kegiatan ini adalah dalam bentuk pelatihan atau training singkat pengelolaan keuangan rumah tangga dengan menggunakan modul pengelolaan keuangan. Peserta diberikan pelatihan dengan kegiatan dengan metode klasikal pemberian materi dan dilanjutkan dengan sesi tanya jawab dan Latihan/ Praktek; pemberian kertas kerja yang diisi sesuai dengan kondisi riil peserta. Peserta kegiatan yaitu para ibu rumah tangga yang tidak bekerja, ibu rumah tangga yang bekerja, dan ibu rumah tangga yang memiliki bisnis sendiri dengan latar belakang pendidikan rata-rata sampai sekolah menengah, serta latar belakang ekonomi keluarga menengah kebawah dapat mengikuti pelatihan dengan baik dan antusias.
\end{abstract}

Kata Kunci:Pengelolaan keuangan rumah tangga, kesejahteraan keluarga

\section{PENDAHULUAN}

Keuangan adalah masalah umum yang dihadapi oleh setiap orang. Semua orang pasti berhubungan dengan uang, baik sebagai individu yang telah menikah maupun yang belum menikah, perorangan maupun perusahaan. Seringkali timbul permasalahan bagaimana cara mengatur keuangan yang kita miliki. Umumnya masalah bukan terletak pada penghasilan yang kurang namun adanya kebiasaan yang salah dal am mengelola keuangan.

Banyak orang yang mengalami kesulitan dalam mengelola keuangan keluarga karena tidak dapat mengontrol keinginan. Orang-orang yang mengalami kesulitan mengelola keuangan keluarga seringkali salah memprioritaskan pengeluarannya. Mengelola Ekonomi Rumah Tangga (ERT) adalah tindakan untuk merencanakan, melaksanakan, memonitor, mengevaluasi dan mengendalikan perolehan dan penggunaan sumber-sumber ekonomi keluarga khususnya keuangan agar tercapai tingkat pemenuhan kebutuhan secara optimum, memastikan adanya stabilitas dan pertumbuhan ekonomi keluarga (Novita Anggraeni, 2012).

Mengelola keuangan keluarga nampaknya begitu sederhana. Namun dalam praktiknya banyak sekali orang yang tidak mampu mengelolanya dengan baik. Ini bukan soal besar atau kecilnya gaji/ pendapatan yang diterima, melainkan bagaimana membelanjakan uang yang ada secara terarah sesuai dengan peruntukan berdasarkan skala prioritas. Alokasi anggaran dan belanja keluarga (rumah tangga) yang sederhana ini jika tidak dikelola dengan baik maka melahirkan keluarga-keluarga yang gali lobang tutup lobang. Hidup selalu kurang dan kurang lagi, meskipun nominal pendapatan telah mengalami peningkatan. 
Hal tersebut tentu bukan sekedar masalah pribadi semata, karena langsung atau tidak langsung akan berpengaruh terhadap performa seseorang dalam bekerja di lingkungan kerjanya masing - masing. Coba bayangkan bagaimana seseorang bisa bekerja dengan baik, penuh integritas dan dedikasi jika gaji yang ia terima setiap bulan hanya setengah atau kurang dari nominal yang harus diterima, karena banyaknya hutang/ potongan pinjaman, atau gaji yang ia peroleh hanya cukup sampai pertengahan bulan, setelah itu mencari pinjaman dan pinjaman lagi.

Pada banyak keluarga dimana ayah sebagai pencari nafkah utama dan ibu sebagai ibu rumah tangga yang tidak mempunyai penghasilan sendiri, maka peran ibu untuk mengatur pengelolaan keuangan keluarga sangat diharapkan. Dengan latar belakang pendidikan para ibu yang berbagai macam, masalah pengelolaan keuangan rumah tangga adalah hal yang dapat terjadi di setiap rumah tangga tanpa melihat latar belakang pendidikannya.

Merupakan fenomena yang sangat umum terjadi yaitu sebagian besar ibu-ibu rumah tangga mengelola keuangan rumah tangga tanpa melakukan perencanaan, mengalir begitu saja. Sehingga dari berdasarkan hasil kegiatan sebelumnya di wilayah kelurahan Kebon Jeruk ditemukan bahwa para ibu rumah tangga ini kesulitan dalam menyisihkan uangnya untuk ditabung. Sebagian besar mereka hanya ibu rumah tangga tanpa penghasilan, beberapa memiliki penghasilan sendiri dengan berprofesi sebagai guru PAUD, membuka warung tradisional, penjual jamu dan penjual nasi uduk. Mereka kesulitan mengatur keuangan rumah tangganya, pengeluaran mereka lebih besar daripada penghasilan yang diterima.

Sasaran dari program pelatihan pengelolaan keuangan rumah tangga ini adalah para ibuibu rumah tangga di wilayah Cengkareng Barat di Jakarta Barat. Berdasarkan wawancara dengan beberapa ibu, kendala utama pengelolaan keuangan terletak pada ketidakpahaman para ibu bahwa keuangan rumah tangga perlu dikelola, dicatat, dianggarkan, dievaluasi, serta melakukan investasi untuk masa depan rumah tangga.

Setelah mengikuti pelatihan ini, semua peserta akan memiliki kesadaran, pola fikir dan pola sikap hidup yang konstruktif terutama dalam hal pemanfaatan pendapatan keluarga, serta mampu menggunakannya sesuai alokasi dan peruntukan berdasarkan skala prioritas keluarga. Target yang dituju dalam kegiatan ini adalah para ibu rumah tangga di wilayah Cengkareng Barat, Jakarta Barat.Dimana antara lain sebagai ibu rumah tangga yang tidak bekerja, ibu rumah tangga yang bekerja, dan ibu rumah tangga yang memiliki bisnis sendiri dengan latar belakang pendidikan rata-rata sampai sekolah menengah, serta latar belakang ekonomi keluarga menengah ke bawah. Jumlah peserta yang hadir sebanyak 25 orang dan selain ibu rumah tangga juga terdapat peserta yang belum menikah masih kuliah, mereka tertarik mengikuti pelatihan ini untuk menambah bekal pengetahuan sebelum berumah tangga.

\section{MATERI DAN METODE}

Untuk mengatasi permasalahan tersebut sebagaimana disebutkan dalam bab 1, maka dapat dilakukan berbagai pemecahan masalah sebagai berikut;

1. Memberi pemahaman mengenai pentingnya pengelolaan keuangan dalam rumah tangga agar dapat meningkatkan tabungan dan investasi.

2. Melakukan praktik mencatat penerimaan dan pengeluaran dan membuat anggaran rumah tangga. 


\section{Khalayak Sasaran Strategis}

Khalayak sasaran yang strategis dalam kegiatan ini adalah Ibu- ibu PKK di Cengkareng, Jakarta Barat sejumlah 25 orang.

\section{M etode Kegiatan}

Metode yang digunakan dalam kegiatan ini adalah dalam bentuk pelatihan atau training singkat pengelolaan keuangan rumah tanggadan investasi dengan menggunakan modul pengelolaan keuangan. Peserta yang berasal dari ibu-ibu rumah tangga di Cengkareng wilayah Jakarta Barat diberikan pelatihan dengan kegiatan berupa :

1. Metode klasikal pemberian materi dan dilanjutkan dengan sesi tanyajawab

2. Metode Latihan/ Praktek; pemberian kertaskerjayang diisi sesuai dengan kondisi nil peserta

\section{HASIL DAN PEMBAHASAN}

Tingkat inflasi yang semakin tinggi memberikan dampak yang cukup signifikan terhadap peningkatan pengeluaran atau biaya di dalam rumah tangga. Peningkatan pengeluaran keluarga ini menjadi masalah yang cukup serius di dalam perekonomian keluarga dan menjadi faktor yang sangat berpengaruh terhadap meningkatnya angka perceraian. Kurangnya kesadaran dari Para Ibu bahwa mereka memiliki peran yang sangat luar biasa dalam mengelola keuangan keluarga menyebabkan para ibu memiliki keterbatasan dalam mengelola keuagan. Kurangnya kesadaran ini didukung oleh minimnya pengetahuan dan ketrampilan para ibu dalam mengelola keuangan keluarga. Untuk Tim Pengabdian Masyarakat Universitas Mercu Buana melakukan pengembangan kepada Para Ibu untuk dapat mengel ola keuangan keluarga dengan lebih baik.

Kegiatan Pengabdian ini akan dievaluasimelalui pemberian kertas kerja dengan cara belajar dalam menulis suatu transaksi secara sederhana, untuk mengetahui peningkatan pengetahuan manajemen keuangan. Selain itu, melalui kegiatan pendampinganyang dilakukan setelah pelatihan, tingkatkeberhasilan kegiatan pengabdian ini juga dapat diketahui.

Pelaksanaan kegiatan Pengabdian Pada Masyarakat ini dilakukan dengan menggunakan metode ceramah, tutorial, dan diskusi. Adapun tahapan pelaksanaan kegiatan pengabdian ini adalah sebagai berikut:

1. Langkah 1 (Metode Ceramah) :

Peserta diberikan wawasan mengenai pentingnya manajemen keuangan dalam memulai maupun menjalankan usaha. Langkah pertama diselenggarakan melalui metode ceramah selama 25 menit. 


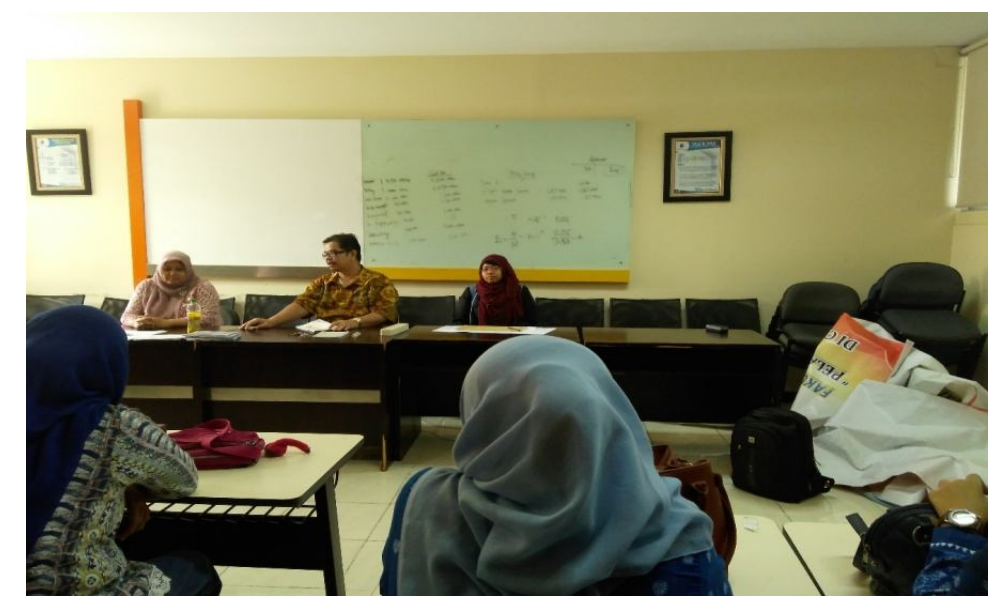

Gambar 1. Pemberian Materi Ceramah

Sumber: Dokumentasi Tim Pelaksana (2018)

2. Langkah 2 (Metode Tutorial):

Peserta pelatihan diberikan materi tentang penyusunan laporan keuangan, meliputi: Iaporan laba rugi, laporan perubahan modal, neraca serta laporan arus kas. Materi ini disampaikan dalam bentuk tutorial disertai dengan latihan/ studi kasus. Langkah kedua diselenggarakan selama 1 jam.

\title{
3. Langkah 3 (Metode Diskusi):
}

Peserta pelatihan diberikan kesempatan untuk mendiskusikan permasalahan yang berkaitan dengan usaha yang sudah mereka jalani ataupun hal-hal yang ingin mereka tanyakan untuk memulai usaha. Langkah ketiga diselenggarakan selama 1,5 jam.

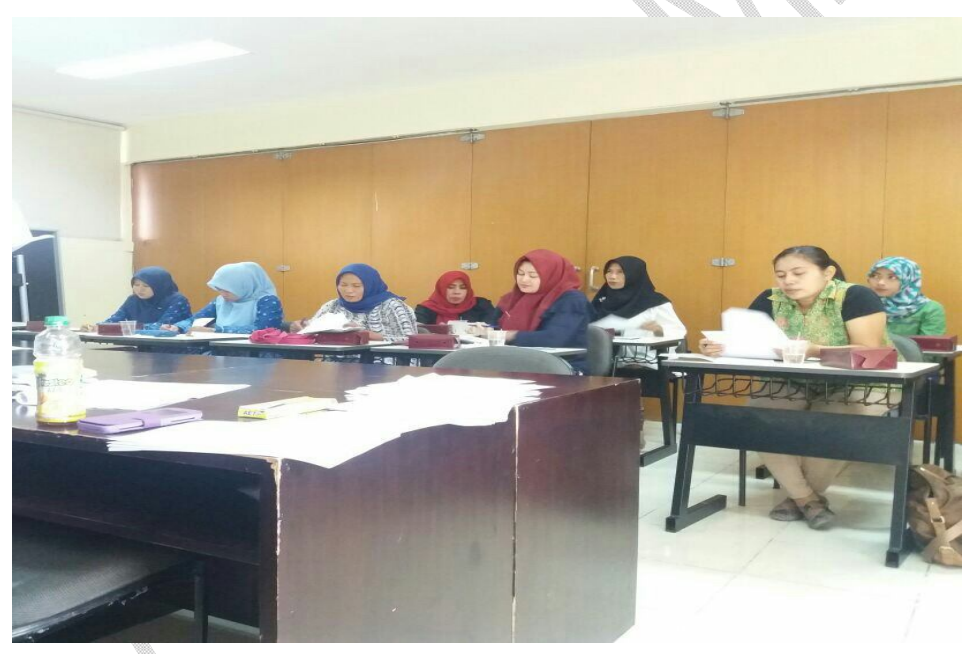

\author{
Gambar 2. Peserta \\ Mendengarkan Pemaparan \\ Materi \\ Sumber: Dokumentasi Tim \\ Pelaksana (2018)
}

Disamping langkah 1, 2, dan 3 di atas, akan dilakukan kegiatanpendampingan untuk menyusun laporan keuangan usaha

\section{Evaluasi Kegiatan}

Bentuk evaluas yang dilakukan dalam kegiatan ini adalah memberikan Tanya jawab kembali kepada para peserta. Hasilnyaadalah sebesar $90 \%$ memberikan penilaian baik dan para peserta 
paham bagaimana pencatatan pengelolalan keuangan secara sederhana. Mereka berharap kegiatan ini sering dilakukan dan merekaberharap acara selanjutnya bagaiaman melakukan penanaman hidrohonik agar masyarakat mulai menanam sayuran di atas air.

\section{Hasil Diskusi}

Pengelolaan keuangan rumah tangga bertujuan untuk mendayagunakan kesadaran, sikap, perilaku, dan kemampuan anggota keluarga, serta menggerakkan potensi ekonomi keluarga. Hal ini guna memastikan adanya pemenuhan kebutuhan ekonomi anggota keluarga secara optimum, terciptanya stabilitas kehidupan ekonomi keluarga, serta pertumbuhan ekonomi keluarga. Prinsip pengelolaan ekonomi rumah tangga adalah adanya upaya untuk meningkatkan pendapatan dan pengendalian tingkat pengeluaran dalam memenuhi kebutuhan anggota keluarga agar terdapat surplus secara kontinyu diakumulasikan menjadi kekayaan yang semakin besar.

Masalah utama dalam pengel olaan keuangan rumah tangga adalah penghasilan keluarga tidak dapat mencukupi kebutuhan pengeluaran keluarga sehingga lebih besar pengeluaran daripada pendapatan. Masalah lainnya yang umumnya terjadi pada rumah tangga yang penghasilannya berlebih adalah tidak dapat mengelola pengeluarannya sehingga hanya cukup untuk memenuhi kebutuhan namun tidak dapat menyisihkan untuk disimpan atau diinvestasikan. Oleh karena itu, pemahaman mengenai pengelolaan keuangan rumah tangga dan pengenalan investasi sangat penting bagi para ibu untuk meningkatkan kesejahteraan keluarga sebagai bagian dari kesejahteraan masyarakat.

\section{KESIMPULAN}

Banyak orang beranggapan bahwa Manajemen keuangan keluarga merupakan salah satu bidang yang rumit. Sebenarnya manajemen keuangan keluarga tidaklah rumit seperti yang dibayangkan banyak orang, khususnya ibu-ibu yang sering di daulat sebagai manajer keuangan keluarga. Untuk menjadi manajer keuangan keluarga yang cerdas dan bijak, tidaklah harus menjadi seorang ahli keuangan.

Manajemen keuangan keluarga memang membutuhkan pengetahuan dan kearifan dalam menjalankannya. Kebanyakan orang yang merasa terintimidasi dengan masalah ini, malah mengabaikannya. Persoalaan ini harusnya menjadi prioritas keluarga karena banyak sekali masalah timbul karena kurang bijaknya manajer keuangan keluarga dalam mengelola dan mengatur keuangannya. Sebagai seorang manajer keuangan keluarga, ada beberapa aspek yang perlu ditangani yaitu:

a. Membuat dan meninjau secara perisodik prioritas keuangan keluarga.

b. Mengelola pendapatan yang terbatas secara bijak.

c. Menghitung kebutuhan proteksi serta menginvestasikan dana dalam bentuk investasi yang sesuai.

d. Menentukan sebuah rencana pensiun.

e. Mempersiapkan dana pendidikan untuk anak-anak.

f. Belanja dengan bijak.

g. Mengajarkan anak-anak mengenai keuangan

Berdasarkan sharing yangdilaksanakan pada saat diskusi, tidakada kesan buruk dari peserta selamapelaksanaan kegiatan, baik dari segisarana dan prasarana maupun penyampaian materi, hanya saja perludibuat dalam skala yang lebih luas. 
Pengabdian selanjutnya diarahkanpada sharing masalah pengeloaankeuangan tetapi dengan tema danobjek yang berbeda.

\section{REFERENSI}

IkatanA kuntan Indonesia. (2009). StandarA kuntansiKeuanganEntitasTanpa AkuntabilitasPublik. Sal embaEmpat. Jakarta.

Senduk. S.(2004). Seri PerencanaanKeuanganKeluarga :Mempersiapkan Dana PendidikanAnak. Jakarta: Elex Media Komputindo.

\section{A bout Author}

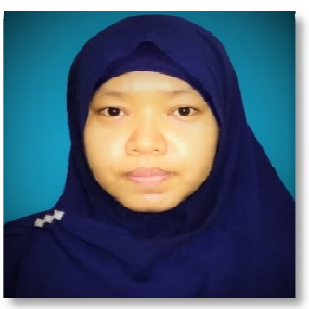

Swarmilah Hariani Batubara, SE.,M.Acc.,CIBA.,CBV, Lahir di Mompang Jae, 31 Maret 1988. Penulis merupakan dosen di Universitas Mercu Buana Jakarta. Saat ini penulis sedang melanjutkan Program PhD di Malaysia. Penulis mengembangkan karirnya sejak tahun 2013 dengan pengalaman mengajar matakuliah Akuntansi Publik. Email: swarmilah@mercubuana.ac.id

\section{FUNDING}

Kegiatan ini merupakan bagian dari program Pengabdian Kepada Masyarakat yang didanai oleh Fakultas Ekonomi dan Bisnis Universitas Mercubuana tahun 2018.

\section{COM PETING INTERESTS}

Tidak ada konflik kepentingan untuk diungkapkan.

Accepted author version posted online: 31 August 2019

Hendryadi (Reviewing editor) 
This page intention to blank...........

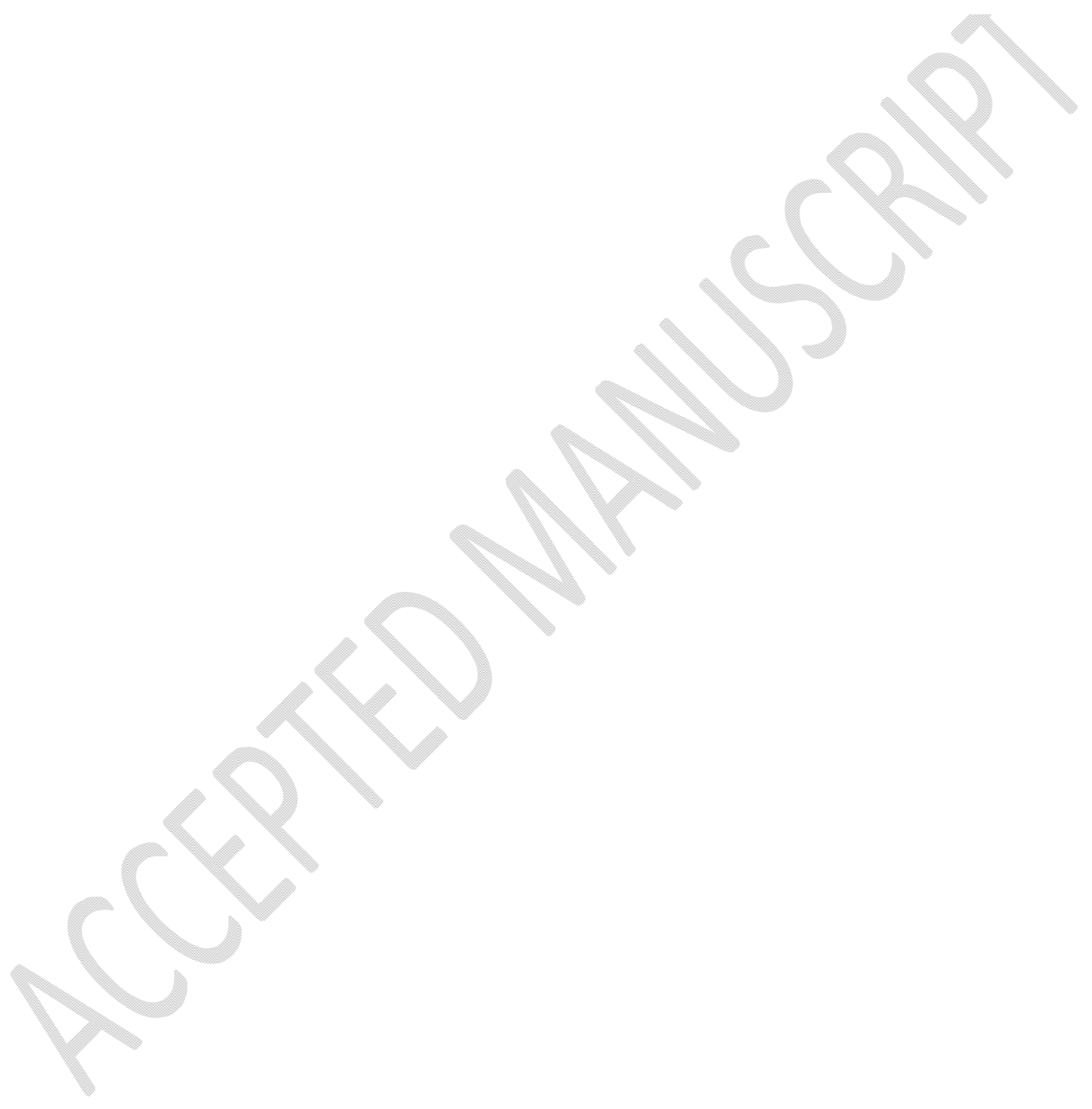

